\title{
The Effect of Use of Native-accent and Non-native Accent Materials on the Iranian EFL Learners' Listening Comprehension: An EIL Perspective
}

\section{Arash Saharkhiz Arabani ${ }^{1}$, Jalil Fathi ${ }^{2 *}$, \& Reyhaneh Balalaei Somehsaraei ${ }^{1}$}

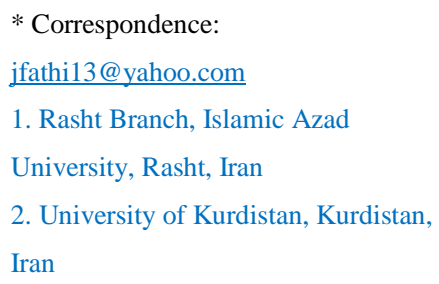

Received: 23 April 2019

Revision: 22 June 2019

Accepted: 5 July 2019

Published online: 20 September 2019

\begin{abstract}
The present study sought to investigate the differential effect of using nativeaccent and non-native accent materials on the Iranian English as a Foreign Language (EFL) learners' listening comprehension. To this purpose, 60 primary EFL Iranian learners participated in the study. The participants were randomly divided into a control group $(\mathrm{N}=30)$ and an experimental group $(\mathrm{N}=30)$. First, a Quick Placement Test which consisted of vocabulary, grammar, and reading items was administered in order to ensure the homogeneity of participants. As the intervention of the study, the control group was provided with the listening materials accompanied by the use of their native-accent audio files, whereas the experimental group was exposed to the same listening tasks and materials which were pronounced by the nonnative teacher. The experimental intervention lasted for six forty-minute sessions. To collect the data, the listening component of Pearson Test of English General (PTE General) was used as the pre-test and the post-test to measure listening comprehension of the participants. The results indicated that using non-native accent listening materials was more effective than using native-accent materials in enhancing listening comprehension of the EFL learners. These findings were discussed in the light of English as an International Language (EIL) debate and the theory of inter-language speech intelligibility benefit.
\end{abstract}

Keywords: EFL learners, listening comprehension, listening materials, native speaker, EIL 


\section{Introduction}

Listening in second language (L2) is of immense significance for language learners and is regarded as the most demanding skill by some L2 researchers (Graham, 2003). L2 listening is viewed as a perceptual process which posits learners to utilize auditory phonetics in order to organize, detect, and overcome lexical segmentation inadequacies (Field, 2003). Moreover, listening comprehension is a complicated and demanding process which requires employing both linguistic knowledge and schematic knowledge to comprehend the aural texts (Pourhosein Gilakjani \& Sabouri, 2016; Vandergrift \& Baker, 2015). In spite of its importance and complexity for L2 learners, listening has remained under-researched in comparison with other skills and there has been a gap between theory and practice in L2 listening learning and pedagogy (Graham, 2017; Vandergrift, 2007).

As far as listening in a foreign language is concerned, taking native-like or authentic accent as the appropriate model for listening materials has taken precedence on the grounds that exposure to aural input is scanty in foreign language contexts. In spite of its various definitions, authenticity may be commonly conceptualized as unchanged and nonmanipulated materials produced by native speakers and for the natives themselves (Bacon, 1992; Scarcella \& Oxford, 1992). Such materials might be spoken or written materials used in real contexts by target language users (Rogers $\&$ Medley, 1988). In addition to the native speaker privilege associated to authentic and native-accent materials, it is also argued that comprehending authentic materials is not demanding because of some features of spoken language such as hesitation, pausing, repetition, redundancy, and rephrasing (Bacon, 1989; Schmidt-Rinehart, 1994).

For a long time in history of applied linguistics, native speaker language has been considered as the most accurate source of data and as the most reliable yardstick against which language competence can be measured (García \& Wei, 2014; Ó Murchadha \& Flynn, 2018). As a result, language proficiency development for L2 learners has been frequently conceptualized as further approximation to the norms of native speakers by many L2 theoreticians, policymakers, and practitioners (Jenkins \& Leung, 2016). Raised in such an educational milieu, L2 learners themselves have craved to become like a native (Butler, 2007).

\subsection{Statement of Problem}

Although sticking to the native speaker norms has taken much precedence for L2 practitioners and learners, this seemingly warranted perspective has not remained indisputable. There exists an accumulated bulk of literature which questions and criticizes the legitimacy of native speaker norms as the ideal norms for L2 learners (Cook, 2016; Piller, 2001). Nowadays, English is no longer the sole possession of native speakers but it is a lingua franca which is everincreasingly used as a medium of communication by different people with various 'linguacultural backgrounds' (Jenkins, 2009, p. 200). With the advent of English as a lingua franca and its reconceptualization as an international language, the notion of world Englishes, which legitimized different varieties of English, received significant recognition and approval (Kachru, 1985).

In line with this shift of attention away from native speakers towards recognizing non-native speakers, numerous researchers have called for incorporation of different varieties of accents especially L1 accent in the classroom (Kopperoinen, 2011). However, L2 teachers and practitioners have left unsupported on how to include such multiple varieties of accents in their own classrooms (Sung, 2016). As far as L2 listening research is concerned, the effect of accent on listening comprehension has received research attention recently (Kang, Thomson, \& Moran, 2019). Within this line of enquiry, it is argued that the type of accent and accented speech affects the degree of listening comprehension (Rubin, 1992). In light of this theoretical and empirical backdrop and as an attempt to address some of the gaps raised above, the present study was set to investigate the effect of using native-accent and non-native accent materials on the Iranian EFL learners' listening comprehension.

\subsection{Research Question}

To accomplish the main objective of the present study, the following research question was raised:

RQ: Is there any significant difference between primary EFL learners who are taught using native listening materials and those who are instructed using non-native accent (i.e., teacher accent) listening materials in terms of their listening comprehension?

\subsection{Null Hypothesis}

In order to investigate the above research question, the following null hypothesis was formulated: 
H0: There is not any significant difference between primary EFL learners who are taught using native listening materials and those who are instructed using non-native accent (i.e., teacher accent) listening materials in terms of their listening comprehension.

\section{Review of the Literature}

As discussed above, the prestige associated to the native speaker norms as the ideal model for L2 learning mostly originates from an inveterate ideology acknowledging the standard and correct use of language. Within this line of reasoning, native speakers were considered as the only ones who could set the standards for the correct use of the language and the native model of language should be emulated by the learners (Canagarajah, 1999). Subscribing to this view, numerous researchers attributed much privilege to using authentic or native accent materials in L2 listening instruction (Porter \& Roberts, 1981). As a result, numerous empirical studies have been conducted to explore the effectiveness of authentic native-accent materials in L2 classes. To ground the purpose of the present study, some more illuminative studies are reviewed in this section. For example, Mousavi and Iravani (2012) compared the effects of use of authentic and non-authentic aural materials on the listening performance of EFL learners. The participants of the study were eighty upper-intermediate language learners randomly selected from language learning centers in Iran. The students were assigned to one group taught with authentic materials and one group with non-authentic materials. The experimental intervention lasted for one semester in which the authentic group was provided with authentic radio-tapes, whereas, the non-authentic group was given various aural materials adapted from the assorted non-authentic sources. The findings of the study indicated that the authentic group outperformed the non-authentic group in terms of listening comprehension at the end of the experiment.

In another study, Sabet and Mahsefat (2012) investigated the effect of using authentic listening materials on listening performance of EFL university students. For the purpose of this study, 60 elementary students were randomly assigned to an experimental group who was provided with authentic aural materials and a control group who was given simplified materials. A proficiency test including listening comprehension and listening perception sub-tests was administered to the participants. In addition, a leaner feedback survey was administered to the participants of the experimental group to uncover their perceptions of the authentic materials. The findings of the quantitative data indicated that the experimental group students outperformed those of control group in terms of listening performance. In addition, the results of feedback survey showed that the experimental group students held positive attitudes towards authentic listening materials.

In another study, Ahmadi (2016) explored the effects of using authentic aural materials on Iranian EFL learners' listening achievement, their used listening strategies, and their listening problems. The participants were a sample of English major students. The required data were collected through survey. The results of this study revealed that using authentic listening materials had positive effects on the learners' listening comprehension and listening strategies. Similarly, in another study, Ghaderpanahi (2012) investigated the effect of authentic listening materials on the listening comprehension of a sample of Iranian EFL students. The participants of this study were 30 female undergraduate students of psychology. During the intervention, the participants of the study were provided with both authentic listening materials and opportunities to do authentic listening tasks. The results of both quantitative and qualitative data revealed that the use of authentic aural materials was conducive in improving listening performance of the participants.

Concerning the effect of native and non-native pronunciation of teachers on L2 learners' performance, Levis et al. (2016) examined the impact of teachers' L1 on the learners' ratings of the degree of comprehensibility and accentedness. The participants were two intact English groups. One group was taught by a native teacher and the other one was instructed by a non-native teacher using the same listening materials for a period of seven weeks. The findings revealed that although students showed more preference to native teachers, there was no significant difference between learners' ratings of comprehensibility for both native and non-native teachers. In another study, Kang, Thomson, and Moran (2019) investigated the impact of including different varieties of English accents in a listening section of a mock test of English as a foreign language (TOEFL) test on leaners' degree of comprehensibility. In so doing, speakers of six distinct English varieties were employed to produce speech samples for the listening test. Then the speakers of those same six varieties of English were employed to take the mock test. The findings revealed that if accented English was very intelligible, listening scores for stimuli produced by high proficient speakers of non-native varieties of English were not significantly lower than those for stimuli based on native varieties of English. Overall, it was 
concluded that when learners were exposed to the highly understandable speech only, shared L1 had no effect on the listeners.

With regard to the use of authentic materials, Namaziandost, Esfahani, and Hashemifarnia (2018) investigated the effectiveness of employing authentic videos in improving Iranian EFL students' prosodic competence. In so doing, forty Iranian intermediate EFL learners were randomly selected and assigned to an experimental group and a control group. The homogeneity of groups was ensured via administering a pre-test. Then for the purpose of the study, the control group was instructed prosodic dimensions of language using a traditional method whereas the experimental group was instructed via using authentic videos. The findings of the study revealed that experimental group significantly outperformed the control group, suggesting that use of authentic videos significantly contributed to improving students' prosodic ability. In another study, Zhiying (2018) explored the effects of various accents on L2 learners with different proficiency levels. To achieve the objectives of this study, the impact of using three types of accents including British, Australian, and Indian accents on L2 listening comprehension were investigated. The findings of the study revealed that accent has an identical effect on high- and low-proficiency students. Moreover, it was found that accent familiarity could affect listening comprehension and accent preference although these influences were not substantial.

In a recent study, Emerick (2019) explored the beliefs of language teachers regarding explicit teaching and use of authentic materials in L2 listening instruction. The participants were L2 teachers of eight universities in the United States. To collect the data, both a questionnaire and semi-structured interviews were conducted. The results revealed that teachers considered explicit listening instruction necessary for L2 learning. Moreover, the majority of teachers found authentic listening materials as essential and effective for L2 learners.

\section{Methodology}

\subsection{Design of the Study}

This study was a quantitative, experimental design which included two variables, with the listening comprehension as the dependent variable and the accent of the listening materials in use as the independent variable. To choose homogeneous participants, a general proficiency test was given to the participants. Afterwards, the primary level participants were randomly divided into two groups (native-accent materials versus teacher-accent materials). Then in order to measure the listening performance of the participants before treatment, a listening pre-test was administrated to the participants of both groups. Afterwards, to achieve the objectives of the study, two different listening materials were presented to the groups as the treatment. At the end, a listening comprehension post-test was administered and the collected data were analyzed via Statistical Package for the Social Sciences (SPSS).

\subsection{Pilot Study}

Before administering the pretest and posttest, the researchers piloted them with a pre-test group (n=15) who were at the same level of the participants of the study. The face and content validity of the tests were also verified by two experts in the area of language testing and the reliability of the tests was calculated through KR-21. In addition, to make sure about the allotted time, the tests were piloted prior to the experiment and the time period in which the pilot group students completed the tests was seven minutes without any pause between the test items.

\subsection{Participants}

All the EFL learners who enrolled in the primary level at a language institute in Rasht (Guilan, Iran) were asked to take Quick Placement Test (QPT) so that the researchers could choose the learners who were at the primary level of language proficiency. Thus, thirty primary learners who scored from one to 17 were assigned into two experimental groups. Each class had 30 learners. The participants were all female high-school students and their ages ranged from 15 to 17 . In addition, the teacher who was one of the present researchers represented the non-native accent in the treatments. She was born and grew up in Iran and had learned English from adolescence and had never been to any English-speaking foreign country. Therefore, all the EFL learning experience of the teacher had taken place in an Iranian EFL context and through classroom instruction in language institutes, university education, and self-study. She was 26 at the time of the study and was an MA student in TEFL in Rasht, Iran. She learned English at different language institutes in Rasht for four years before entering the university. She also got her BA in English Language and Literature at another university in Rasht. In addition, she had been teaching English to different ages and proficiency levels for eight years at various language institutes at the time of the study. 


\subsection{Materials}

\subsubsection{Quick Placement Test (QPT)}

In order to get homogenized groups of participants, a QPT which included vocabulary, grammar, and reading questions was used. The first part of this test included 40 multiple-choice items of grammar and vocabulary from simple to difficult and from primary to intermediate. According to the test rubrics, the participants who scored one to 17 were considered to be at the primary level and those who scored above 17 were excluded from the study.

\subsubsection{The Pre-test and the Post-test}

For the purpose of this study, the pre-test and post-test were adapted from The Pearson Test of English General (PTE General) Level A1 consisting of 10 items of listening comprehension which the learners had to answer in 15 minutes. While the learners were reading and answering the tests, the researchers did not observe any problems related to the content of both the pre-test and post-test. In order to answer the items, 15 minutes was given to the students within a 30-second pause between the played items.

\subsection{Data Collection}

For the starting point, in order to have homogeneous samples, QPT was given to 118 participants to choose the primary level learners. The learners who obtained one to 17 in the test were chosen to participate in the current study. A total number of 60 EFL learners were selected based on their performance on QPT. Then the selected participants were randomly assigned into two groups, namely control and experimental each including 30 participants. Later, the researchers named the groups as, native-accent material and teacher-accent material. A General, level A1, PTE Test consisting of 10 items of listening comprehension was administered as a pre-test to both of the groups at the beginning of the study and before teaching the listening tasks.

In the next phase, the instruction was presented twice a week in six sessions consecutively by one of the researchers. Each class session lasted for 90 minutes; after the initial 20 minutes of reviewing the previous lesson, getting feedback and engaging learners in the new lesson's topic, the researchers used 40 minutes of each session working on the listening tasks which were allocated to teaching listening comprehensions presented in various forms. Both groups used the same textbooks (Happy Street 2, including Class Book and Work Book, from the Happy Street series, published by Oxford University Press), taught by the same instructor.

The textbook allocated to this study contained eight pages in each unit, in six of which, the listening tasks were included. The researchers designed the plan and chose the pages in a way to have at least one listening task from the textbook every session, although the type of activities and the focus of the author was on different areas in each lesson, ranging from teaching new vocabularies and grabbing the learners' attention to the topic through a story in the first session to teaching new grammatical rules or giving extra information about the topic through a song and an extended reading in the second session. This process continued during all the considered sessions in different formats but with the same attitude and goal. It is also worth mentioning that in two of these six sessions, the time allocated for the listening tasks by the textbook was between 20 and 25 minutes, which was less than 40 minutes. In this situation, the researchers managed the challenge by using a story book (Super Sam, Dolphin Readers series, level 2) which included original CDs with Native American accent narrators in the control group class and the teacher-accent material in the experimental group class to compensate for the arranged time.

As mentioned above, in both classes, the same course-book, pages, and listening items were taught. Also, the teaching methods implemented in both classes were approximately the same. The course-book included listening tasks in the form of stories, songs, dialogues, extended readings, and additional warm up and reinforcement workbook activities besides Storybook listening tracks (benefited in some sessions). In nearly all the cases, the researchers started the process by engaging students in the new topic they were going to study and then continued by pre-teaching the new vocabulary as they were written on the board. Next, the learners opened the book and answered some questions about the drawings or pictures of the intended page. Finally, it was time for the listening tasks to be implemented. In this phase, the researchers applied the considered changes by using native accent materials and non-native ones. Also, as an illustration for teaching the extended readings and stories, the instructor wrote some questions on the board and asked the students to listen to the item (in one group via the CDs and in the other via the researcher's own voice) as the books are closed to find the proper answers. If the page presented dialogues or songs, the learners were first supposed to listen carefully (in one group via the CDs and in the other via the researcher's voice), and then learn the 
new word pronunciations and stress patterns besides the sentence intonations and in the end they would apply them through role-playing or singing.

The only distinction between the groups was the fact that the control group (the native-accent materials) used the native-accent materials (original CDs with the American accent narrators) during the class, while the experimental group received the same treatment with the teacher's voice which was a Persian non-native accent of English. As mentioned previously, the teacher was born and grew up in Iran and had learned English from adolescence and had never been to any English-speaking foreign country. Therefore, all the EFL learning experience of the teacher had taken place in an Iranian EFL context and through classroom instruction in language institutes, university education, and self-study. The tasks were performed by the researchers who read the listening tasks' printed transcripts clearly instead of using the original CDs. The tone, intonation, stress, and all the other determining factors in producing proper sound quality outcomes in the experimental group were well-focused by the researchers but still the accent used belonged to the Iranian researcher of the study which had natural shades of her mother tongue (Persian) involved in order to discriminate the results of the study in a better way. The number of repetitions dedicated to listening tasks for each exercise of the textbooks and story book was the same in both control and experimental groups. Most of the listening tasks were run only once, but in cases the students had major understanding difficulties, they were repeated for a second time at most. In all such cases, the number of the repetitions and the type of support and scaffolding provided by the researchers were tried to be kept constant for both groups.

\subsection{Data Analysis}

In order to answer the research question, first both the pre-test and post-test were scored. Then all test results were entered into SPSS to analyze the data. To analyze the results, the quantitative data were analyzed through descriptive statistical methods (mean and standard derivation), and the researchers also ran inferential statistics (i.e., independent samples t-test and paired-samples t-test) to look for any significant statistical differences between the performances of the two groups.

\section{Results}

In order to analyze the collected data for the purpose of the present study, both descriptive and inferential statistics such as independent and paired samples t-tests were carried out. Before conducting the main statistical analyses, normality of the data which is the main assumption of parametric tests was inspected. In addition, the reliability of the listening test was estimated through conducting a pilot study on a small sample $(n=15)$ of EFL students who were similar to the target group in terms of their general foreign language proficiency (primary level). The result of the reliability analysis is presented in Table 1.

Table 1. Reliability statistics for the listening comprehension test

\begin{tabular}{cccc}
\hline & Cronbach's Alpha & N of Items & N of sample \\
\hline Listening comprehension test & .77 & 10 & 15 \\
\hline
\end{tabular}

Moreover, the value of reliability was interpreted according to the reliability standards suggested by Barker, Pistrang, and Elliott (1994) (Table 2). The estimated value of Cronbach's Alpha for the listening test was $(\alpha=.77)$ which was considered acceptable according to the reliability standards suggested by Barker, Pistrang, and Elliott (1994). 
Table 2. Suggested standards for the reliability index (adopted from Barker, Pistrang, \& Elliott, 1994)

\begin{tabular}{ll}
\hline Interpretation & Reliability indices \\
\hline Good & .80 \\
Acceptable & .70 \\
Marginal & .60 \\
Poor & .50 \\
\hline
\end{tabular}

Furthermore, to make certain that the participants of the study were more or less at the same level of foreign language proficiency, Quick Placement Test (version 2) was administered to 118 Iranian EFL learners. The participants took the three parts that included items related to structure, vocabulary, and reading with a maximum possible score of 60 points. Sixty EFL students whose scores fell within the range 1-17 were selected as the main sample for the present study. Based on QPT directions, learners who score within the range of 1-17 are beginner, 18-27 elementary, 28-36 lower intermediate, 37-47 upper intermediate, 48-55 advanced, and 56-60 very advanced. The results of QPT for the participants are presented in Table 3 which shows measures of central tendency including mean, median, and mode as well as measures of dispersion such as range, variance, and standard deviation as well as measures of distribution i.e. skewedness and kurtosis were computed for QPT. For the main study, sixty EFL learners whose scores were within the range of 1-17 were selected.

Table 3. Statistics for QPT

\begin{tabular}{ll}
\hline \multicolumn{1}{c}{ Valid } & 118 \\
\hline \multicolumn{1}{c}{ Missing } & 0 \\
Mean & 18.8898 \\
Median & 17.0000 \\
Mode & 12.00 \\
Std. Deviation & 7.15253 \\
Variance & 51.159 \\
Skewness & .602 \\
Std. Error of Skewness.223 \\
Kurtosis & -.581 \\
Std. Error of Kurtosis & .442 \\
Range & 29.00 \\
Minimum & 7.00 \\
Maximum & 36.00 \\
\hline
\end{tabular}

Then before running the parametric statistical tests (i.e., paired and independent samples t-test), skewedness analysis was run to check out the normality assumption. The results of the skewedness analyses are presented in Table 4 . This analysis was calculated by dividing the statistics of skewedness by the standard error. The statistics of skewedness and kurtosis for the listening comprehension (pre-test control group) equaled to $(.107, .377)$, that for the listening comprehension (pre-test experimental group) turned out to be $(.096,-.396)$. The values of skewedness and kurtosis for the listening comprehension (post-test control group) were $(.377,-.721)$. These values for the listening comprehension (post-test experimental group) were equal to (-..384,-.853), respectively (Table 4$)$. 
Table 4. Statistics for the samples on the pre- and post-tests

\begin{tabular}{|c|c|c|c|c|}
\hline \multirow{2}{*}{$\begin{array}{l}\text { Groups } \\
\text { control group (native- accent material) }\end{array}$} & \multirow{3}{*}{$\mathrm{N}$} & & \multicolumn{2}{|c|}{ Pre-test scores Post-test scores } \\
\hline & & Valid & 30 & 30 \\
\hline & & Missing & 0 & 0 \\
\hline & \multicolumn{2}{|c|}{ Skewness } & .107 & .377 \\
\hline & \multicolumn{3}{|c|}{ Std. Error of Skewness.427 } & .427 \\
\hline & \multicolumn{2}{|c|}{ Kurtosis } & -.505 & -.721 \\
\hline & \multicolumn{2}{|c|}{$\overline{\text { Std. Error of Kurtosis }}$} & .833 & .833 \\
\hline \multirow[t]{6}{*}{ experimental group (teacher-accent material) } & & Valid & 30 & 30 \\
\hline & & Missing & 0 & 0 \\
\hline & \multicolumn{2}{|c|}{ Skewness } & .096 & -.384 \\
\hline & \multicolumn{3}{|c|}{ Std. Error of Skewness.427 } & .427 \\
\hline & \multicolumn{2}{|c|}{ Kurtosis } & -.396 & -.853 \\
\hline & \multicolumn{2}{|c|}{$\overline{\text { Std. Error of Kurtosis }}$} & .833 & .833 \\
\hline
\end{tabular}

These results indicated that the distributions were symmetric and the normality assumption was not violated for the pre- and post-test scores. In other words, values of skewedness and kurtosis were all within the range of \pm 2 for all the distributions. Furthermore, two independent samples t-test procedures were carried out to compare the performance of the two groups (native-accent versus teacher-accent) at pre- and post-tests of listening comprehension. The results of the two independent samples t-tests for the two groups are presented in Table 5.

Table 5. Independent samples t-test for the groups' performance on listening comprehension

\begin{tabular}{|c|c|c|c|c|c|c|c|c|c|}
\hline \multirow[t]{3}{*}{ Outcome } & \multicolumn{6}{|c|}{ Group } & \multirow{3}{*}{$\begin{array}{l}\text { 95\% CI for Mean } \\
\text { Difference }\end{array}$} & \multirow[b]{3}{*}{$\mathrm{t}$} & \multirow[b]{3}{*}{ df } \\
\hline & \multicolumn{3}{|c|}{ Native-accent } & \multicolumn{3}{|c|}{ Teacher-accent } & & & \\
\hline & $\mathrm{M}$ & $\mathrm{SD}$ & $\mathrm{n}$ & $\mathrm{M}$ & $\mathrm{SD}$ & $\mathrm{n}$ & & & \\
\hline Pre-test & 4.46 & 1.69 & 30 & 4.50 & 1.79 & 30 & $-.936, .869$ & -.074 & 58 \\
\hline Post-test & 4.53 & 1.65 & 30 & 5.53 & 1.79 & 30 & $-1.89,-.107$ & $-2.24 *$ & 58 \\
\hline
\end{tabular}

Results of the independent samples t-test for the two groups' performance on listening comprehension indicate that the mean listening comprehension on the pre-test does not significantly differ between native-accent group $(\mathrm{M}=4.46$, $\mathrm{SD}=1.69, \mathrm{n}=30)$ and teacher-accent group $(\mathrm{M}=4.50, \mathrm{SD}=1.79, \mathrm{n}=30)$ at the .05 level of significance $(\mathrm{t}=-.074$, $\mathrm{df}=58, \mathrm{p}<.05,95 \% \mathrm{CI}$ for mean difference -.936 to .869). However, the results of the independent samples t-test for the post-test of listening comprehension show that there is a significant difference between the native-accent group $(\mathrm{M}=4.53, \mathrm{SD}=1.65, \mathrm{n}=30)$ and teacher-accent group $(\mathrm{M}=5.53, \mathrm{SD}=1.79, \mathrm{n}=30)$ at the .05 level of significance $(\mathrm{t}=-2.24, \mathrm{df}=58, \mathrm{p}<.05,95 \% \mathrm{CI}$ for mean difference -1.89 to -.107$)$, suggesting that the listening performance of the teacher-accent group was better than that of the native-accent group on the post-test of listening comprehension. Figure 1 illustrates the comparison between the two groups on pre- and post-test of listening comprehension at the beginning and at the end of the study. 


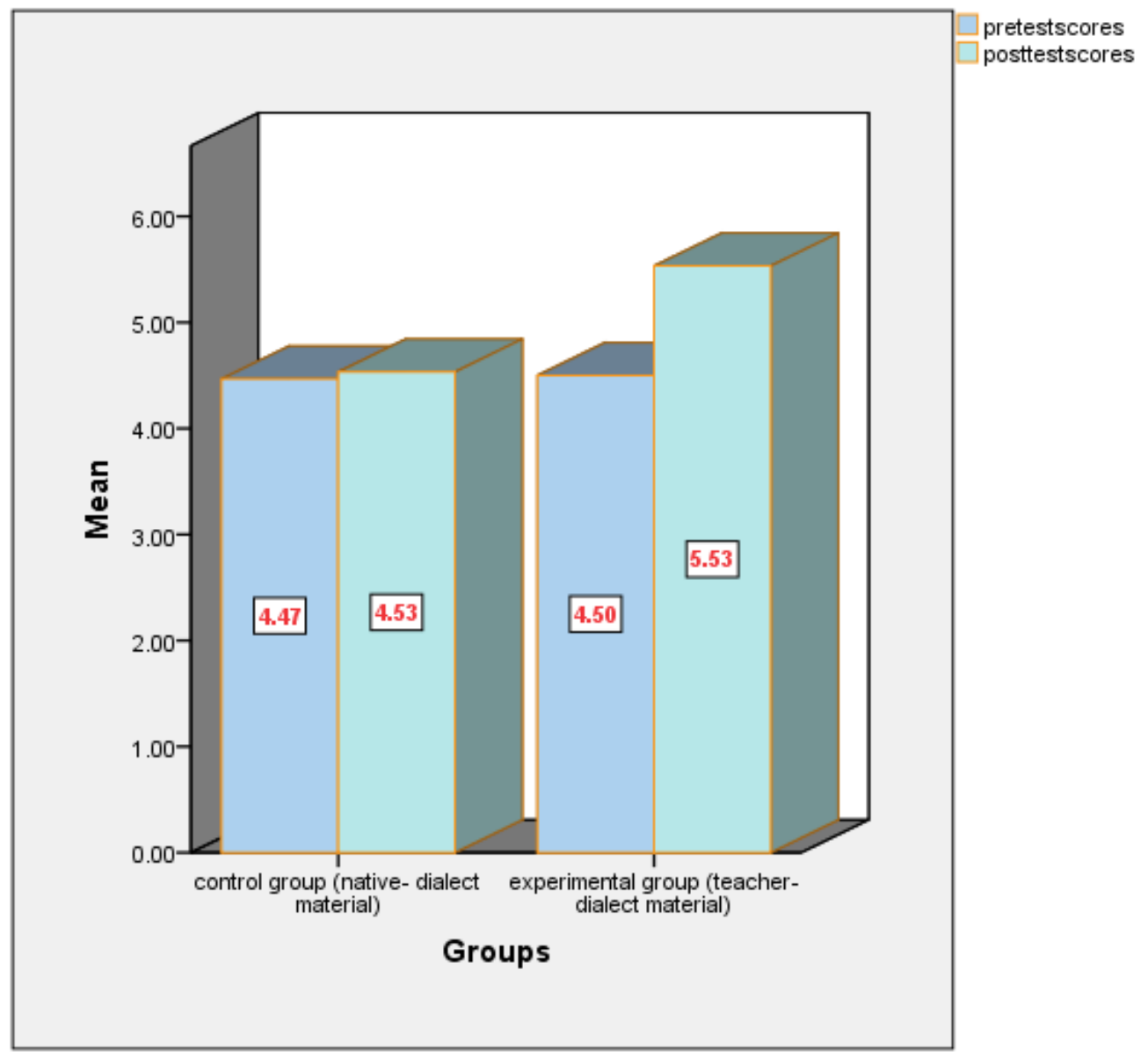

Figure1. The comparison between the two groups on pre and posttest of listening

In addition, in order to investigate the participants' progress within groups from the pre-test to post-test of listening comprehension, two paired samples t-tests were also carried out (Table 6).

Table 6. Paired-samples t-test for the groups' performance on listening comprehension

\begin{tabular}{|c|c|c|c|c|c|c|c|c|}
\hline \multirow[b]{2}{*}{ Outcome } & \multicolumn{2}{|c|}{ Pre-test } & \multicolumn{2}{|c|}{ Post-test } & \multirow[b]{2}{*}{$\mathrm{n}$} & \multirow{2}{*}{$\begin{array}{l}95 \% \text { CI for Mean } \\
\text { Difference }\end{array}$} & \multirow[b]{2}{*}{$\mathrm{t}$} & \multirow[b]{2}{*}{ df } \\
\hline & $\mathrm{M}$ & SD & $\mathrm{M}$ & SD & & & & \\
\hline Native-accent & 4.46 & 1.69 & 4.53 & 1.65 & 30 & $-0.70,0.57$ & -.21 & 29 \\
\hline Teacher-accent & 4.50 & 1.79 & 5.53 & 1.79 & 30 & $-1.59,-0.47$ & $-3.78^{*}$ & 29 \\
\hline
\end{tabular}

Results of the paired-samples t-test indicate that mean listening comprehension of the native-accent group does not significantly differ from the pre-test $(\mathrm{M}=4.46, \mathrm{SD}=1.69)$ to the post-test $(\mathrm{M}=4.53, \mathrm{SD}=1.65)$ at the .05 level of significance $(\mathrm{t}=-.21, \mathrm{df}=29, \mathrm{n}=30, \mathrm{p}<.05,95 \% \mathrm{CI}$ for mean difference -0.70 to 0.57$)$. Nevertheless, the results of the paired-samples t-test show that mean score for listening comprehension of the teacher-accent group differs significantly from the pre-test $(\mathrm{M}=4.50, \mathrm{SD}=1.79)$ to the post-test $(\mathrm{M}=5.53, \mathrm{SD}=1.79)$ at the .05 level of significance $(\mathrm{t}=-3.78, \mathrm{df}=29, \mathrm{n}=30, \mathrm{p}<.05,95 \% \mathrm{CI}$ for mean difference -1.59 to -0.47$)$. These results indicate that 
there was a significant progress in the listening comprehension performance of the teacher-accent group from the pretest to the post-test.

\section{Discussion}

The purpose of this study was set to investigate the differential effect of using native and non-native accent (i.e., teacher accent) listening materials on primary EFL learners' listening comprehension. The findings of the study revealed that the use of non-native or teacher accent materials was more effective in enhancing listening comprehension of the participants. The findings of the present study are in disagreement with the findings of significant number of previous studies (Ahmadi, 2016; Ghaderpanahi, 2012; Mousavi \& Iravani, 2012; Sabet \& Mahsefat, 2012).

The findings of the present study support, in part, the assumptions of the relatively new debate of EIL, which runs counter to the traditional dominance of the native speakers and challenges the widely accepted benefits linked to the use of authentic and native accent materials in the classroom (Canagarajah, 2006; Jenkins, 2006) especially the use of native accent of the students in listening comprehension (Llurda, 2004). Moreover, the findings of the present study can be justified in light of the fact that L2 listeners are more likely to be more exposed to non-native accents than to native, authentic accents in real target-language use contexts (Canagarajah, 2006).

Additionally, even as far as large-scales standardized proficiency tests are concerned, the listening sections of these tests are no longer confined to authentic accent materials and they include a variety of accents in their listening test items (Harding, 2012). The inclusion of non-native or first language accent varieties in both L2 classrooms and highstakes exams has been widely recognized in L2 research (Abeywickrama, 2013; Ockey, Papageorgiou, \& French, 2016).

The findings of this study are partially in line with those of Abeywickrama (2013) who found that using native English accents failed to contribute to improving L2 learners' comprehension performance more than accented language. Likewise, the findings of this study are partially consistent with the findings of Levis et al. (2016) who found that although non-native English-speaking teachers did not have enough confidence to consider themselves as a model in L2 pronunciation, their students perceived the identical level satisfaction with both their native and non-native teachers.

Furthermore, the findings of the present study confirmed the theory of interlanguage speech intelligibility benefit proposed by Bent and Bradlow (2003), suggesting that L2 listeners may have less difficulty understanding the language spoken by a speaker with the same L1. Bent and Bradlow's (2003) study revealed that native accent was more intelligible for native listeners but it was not necessarily the case for non-native listeners. According to their findings, aural speech generated by a relatively high proficiency non-native speakers was as intelligible as the speech produced by a native speaker for the listeners of the same language background, leading to "interlanguage speech intelligibility benefit" (p. 1600). This purported benefit may be attributed to priming of particular acoustic and phonetic characteristics which the speaker and listener might have in common (Pickering, 2006). However, the findings of this study were not confirmed by a number of previous studies (Julkowska \& Cebrian, 2015) which did not lend empirical support for the identical L1 accent benefit on L2 listening performance.

\section{Conclusion}

The objective of the present study was to examine whether there is any significant difference between primary EFL learners who are taught using native listening materials and those who are instructed using non-native accent (i.e., teacher accent) listening materials in terms of their listening comprehension. The results of the study indicated that using non-native or teacher accent materials was more effective in enhancing listening comprehension of the participants. The main implication of the present study may lie in a reconceptualization of an effective language teacher and disentanglement with overshadow of native-speaker norms as a yardstick in evaluating L2 teachers. The results of this study may lend more credit to the claims put forth by EIL debate in emphasizing the fact that sticking to native-speaker norms is not influential in making a teacher be an effective language practitioner. From an EIL perspective, native teachers are not superior to non-natives simply because of their native languages and L2 may be equally well-instructed by both native and non-native teachers, a recently acclaimed stance which assign significant self-confidence to non-native language teachers. EIL perspective may even consider non-native teachers as more effective teachers as they have the experience of learning the language, they are familiar with strategies and have a good pictures of the problems their students might have in learning L2. Advocates of EIL acknowledge and appreciate 
training non-native language teachers based on the grounds that native language teachers are limited in number and L2 teaching profession requires well-trained and qualified L2 teachers.

As a result, effective teachers are not bound to native-speaker and authentic materials any more. But effective teachers are the ones who are able to adapt their employed materials to cater to the needs of the learners with various proficiency levels in different contexts and with various pedagogic objectives. From this perspective, in case the teachers come to realize that listening materials are not adequate or effective enough, they can adapt the materials. As the authentic materials might be difficult for L2 learners, teachers may control the difficulty level by adapting the materials. The findings of the present study may be constrained by some limitations. First, this study used a quantitative quasiexperimental design which can constrain the uncovering of the in-depth understanding of the effects of use of different listening materials on listening comprehension of the participants. Replication of similar studies using qualitative research designs may contribute to researching the immediate insights of the participants on the use of either type of listening materials. Future researchers may also recruit bigger samples of participants with various proficiency levels to enhance the generalizability of the findings to other contexts. Moreover, the duration of the treatment in this study was confined to 6 sessions within a period of three weeks, which is a relatively short intervention period. Similar future studies are recommended to replicate the treatment in a lengthier period of time.

\section{References}

Abeywickrama, P. (2013). Why not non-native varieties of English as listening comprehension test input? RELC Journal, 44(1), 59-74. https://doi.org/10.1177/0033688212473270

Ahmadi, S. M. (2016). An investigation into the effect of authentic materials on Iranian EFL learners' English listening comprehension. International Journal of Research in English Education, 1(1), 38-42. URL: http://ijreeonline.com/article-1-27-en.html

Bacon, S. M. (1989). Listening for real in the foreign language classroom 1. Foreign Language Annals, 22(6), 543550. https://doi.org/10.1111/j.1944-9720.1989.tb02781.x

Bacon, S. M. (1992). Phases of listening to authentic input in Spanish: A descriptive study. Foreign Language Annals, 25(4), 317-333. https://doi.org/10.1111/j.1944-9720.1992.tb00552.x

Bent, T., \& Bradlow, A. R. (2003). The interlanguage speech intelligibility benefit. The Journal of the Acoustical Society of America, 114(3), 1600-1610. https://doi.org/10.1121/1.1603234

Butler, Y. G. (2007). How are nonnative-English-speaking teachers perceived by young learners? TESOL Quarterly, 41(4), 731-755. https://doi.org/10.1002/j.1545-7249.2007.tb00101.x

Canagarajah, A. S. (1999). Resisting linguistic imperialism in English teaching. Oxford University Press.

Canagarajah, A. S. (2006). The place of world Englishes in composition: Pluralization continued. College composition and communication, 57(4), 586-619. https://www.jstor.org/stable/20456910

Cook, V. (2016). Where is the native speaker now? TESOL Quarterly, 50(1), 186-189. https://doi.org/10.1002/tesq.286

Emerick, M. R. (2019). Explicit teaching and authenticity in L2 listening instruction: University language teachers' beliefs. System, 80, 107-119. https://doi.org/10.1016/j.system.2018.11.004

Field, J. (2003). Promoting perception: Lexical segmentation in L2 listening. ELT Journal, 57(4), 325-334. https://doi.org/10.1093/elt/57.4.325

García, O., \& Wei, L. (2014). Translanguaging. The Encyclopedia of Applied Linguistics, 1-7. https://doi.org/10.1057/9781137385765

Ghaderpanahi, L. (2012). Using authentic aural materials to develop listening comprehension in the EFL classroom. English Language Teaching, 5(6), 146-153. https://doi.org/10.5539/elt.v5n6p146

Graham, S. (2003). Learner strategies and advanced level listening comprehension. Language Learning Journal, 28(1), 64-69. https://doi.org/10.1080/09571730385200221 
Graham, S. (2017). Research into practice: Listening strategies in an instructed classroom setting. Language Teaching, 50(1), 107-119. https://doi.org/10.1017/S0261444816000306

Jenkins, J. (2009). English as a lingua franca: Interpretations and attitudes. World Englishes, 28(2), 200-207. https://doi.org/10.1111/j.1467-971X.2009.01582.x

Jenkins J., \& Leung C. (2016) Assessing English as a Lingua Franca. In: Shohamy E., Or I., May S. (eds), Language testing and assessment. Encyclopedia of language and education (3rd ed.). Springer, Cham. https://doi.org/10.1007/978-3-319-02326-7_7-1

Jułkowska, I. A., \& Cebrian, J. (2015). Effects of listener factors and stimulus properties on the intelligibility, comprehensibility and accentedness of L2 speech. Journal of Second Language Pronunciation, 1(2), 211-237. https://doi.org/10.1075/jslp.1.2.04jul

Harding, L. (2012). Accent, listening assessment and the potential for a shared-L1 advantage: A DIF perspective. Language Testing, 29(2), 163-180. https://doi.org/10.1177/0265532211421161

Kachru, B. B. (1985). Standards, codification and sociolinguistic realism: The English language in the outer circle. In Quirk R., Widdowson H. (Eds.), English in the World. Cambridge University Press, Cambridge, UK.

Kang, O., Thomson, R., \& Moran, M. (2019). The Effects of international accents and shared first language on listening comprehension tests. TESOL Quarterly, 53(1), 56-81. https://doi.org/10.1002/tesq.463

Kopperoinen, A. (2011). Accents of English as a lingua franca: a study of Finnish textbooks. International Journal of Applied Linguistics, 21(1), 71-93. https://doi.org/10.1111/j.1473-4192.2010.00263.x

Levis, J. M., Sonsaat, S., Link, S., \& Barriuso, T. A. (2016). Native and nonnative teachers of L2 pronunciation: Effects on learner performance. TESOL Quarterly, 50(4), 894-931. https://doi.org/10.1002/tesq.272

Llurda, E. (2004). Non-native-speaker teachers and English as an international language. International Journal of Applied Linguistics, 14(3), 314-323. https://doi.org/10.1111/j.1473-4192.2004.00068.x

Mousavi, S. A., \& Iravani, H. (2012). The effect of authentic versus non-authentic aural materials on EFL learners' listening comprehension. English Language and Literature Studies, 2(1), 21. https://doi.org/10.5539/ells.v2n1p21

Namaziandost, E., Esfahani, F. R., \& Hashemifarnia, A. (2018). The impact of using authentic videos on prosodic ability among foreign language learners. International Journal of Instruction, 11(4), 375-390. doi: 10.12973/iji.2018.11424a

Ockey, G. J., Papageorgiou, S., \& French, R. (2016). Effects of strength of accent on an L2 interactive lecture listening comprehension test. International Journal of Listening, 30(1-2), 84-98. https://doi.org/10.1080/10904018.2015.1056877

Ó Murchadha, N. O. E. L., \& Flynn, C. J. (2018). Educators' target language varieties for language learners: Orientation toward 'native' and 'nonnative' norms in a minority language context. The Modern Language Journal, 102(4), 797-813. https://doi.org/10.1111/modl.12514

Piller, I. (2001). Who, if anyone, is a native speaker? Anglistik, 12(2), 109-121.

Porter, D., \& Roberts, J. (1981). Authentic listening activities1. ELT Journal, 36(1), 37-47. https://doi.org/10.1093/elt/36.1.37

Pourhosein Gilakjani, A., \& Sabouri, N. B. (2016). Learners' listening comprehension difficulties in English language learning: A literature review. English Language Teaching, 9(6), 123-133. doi:10.5539/elt.v9n6p123

Rogers, C. V., \& Medley, F. W. (1988). Language with a purpose: Using authentic materials in the foreign language classroom. Foreign Language Annals, 21(5), 467-478. https://doi.org/10.1111/j.1944-9720.1988.tb01098.x

Rubin, D. L. (1992). Nonlanguage factors affecting undergraduates' judgments of nonnative English-speaking teaching assistants. Research in Higher Education, 33(4), 511-531. https://www.jstor.org/stable/40196047 
Sabet, M. K., \& Mahsefat, H. (2012). The impact of authentic listening materials on elementary EFL learners' listening skills. International Journal of Applied Linguistics and English Literature, 1(4), 216-229. https://doi.org/10.7575/ijalel.v.1n.4p.216

Scarcella, R. C., \& Oxford, R. L. (1992). The tapestry of language learning: The individual in the communicative classroom (p. 63). Boston: Heinle \& Heinle.

Schmidt-Rinehart, B. C. (1994). The effects of topic familiarity on second language listening comprehension. The Modern Language Journal, 78(2), 179-189. https://doi.org/10.1111/j.1540-4781.1994.tb02030.x

Sung, C. C. M. (2016). Exposure to multiple accents of English in the English Language Teaching classroom: from second language learners' perspectives. Innovation in Language Learning and Teaching, 10(3), 190-205. https://doi.org/10.1080/17501229.2014.936869

Vandergrift, L. (2007). Recent developments in second and foreign language listening comprehension research. Language Teaching, 40(3), 191-210. https://doi.org/10.1017/S0261444807004338

Vandergrift, L., \& Baker, S. (2015). Learner variables in second language listening comprehension: An exploratory path analysis. Language Learning, 65(2), 390-416. https://doi.org/10.1111/lang.12105

Zhiying, W. (2018). The effect of accent on listening comprehension: Chinese L2 learners' perceptions and attitudes. THAITESOL Journal, 31(2), 47-71. 